\title{
Could the Content of Soluble Carbohydrates in the Young Shoots of Selected Willow Cultivars Be a Determinant of the Plants' Attractiveness to Cervids (Cervidae, Mammalia)?
}

\author{
Maciej Budny ${ }^{1}$, Kazimierz Zalewski ${ }^{2, *}$, Lesław Bernard Lahuta ${ }^{3}{ }^{(D)}$, Mariusz Jerzy Stolarski ${ }^{4}(\mathbb{D}$, \\ Robert Stryiński $^{2}$ and Adam Okorski ${ }^{5}$ (D)
}

Citation: Budny, M.; Zalewski, K.; Lahuta, L.B.; Stolarski, M.J.; Stryiński, R.; Okorski, A. Could the Content of Soluble Carbohydrates in the Young Shoots of Selected Willow Cultivars Be a Determinant of the Plants Attractiveness to Cervids (Cervidae, Mammalia)? Agriculture 2021, 11, 67. https://doi.org/10.3390/ agriculture11010067

Received: 20 November 2020 Accepted: 12 January 2021 Published: 15 January 2021

Publisher's Note: MDPI stays neutral with regard to jurisdictional clai$\mathrm{ms}$ in published maps and institutional affiliations.

Copyright: (C) 2021 by the authors. Licensee MDPI, Basel, Switzerland. This article is an open access article distributed under the terms and conditions of the Creative Commons Attribution (CC BY) license (https:// creativecommons.org/licenses/by/ $4.0 /)$
1 Polish Hunting Association, Research Station, Sokolnicza 12, 64-020 Czempiń, Poland; m.budny@pzlow.pl 2 Department of Biochemistry, Faculty of Biology and Biotechnology, University of Warmia and Mazury in Olsztyn, Oczapowskiego 1a, 10-719 Olsztyn, Poland; robert.stryinski@uwm.edu.pl

3 Department of Plant Physiology, Genetics and Biotechnology, University of Warmia and Mazury in Olsztyn, Oczapowskiego 1a, 10-719 Olsztyn, Poland; lahuta@uwm.edu.pl

4 Department of Genetics, Plant Breeding and Bioresource Engineering, University of Warmia and Mazury, in Olsztyn, Plac Łódzki 3, 10-719 Olsztyn, Poland; mariusz.stolarski@uwm.edu.pl

5 Department of Entomology, Phytopathology and Molecular Diagnostics, University of Warmia and Mazury in Olsztyn, Prawocheńskiego 17, 10-719 Olsztyn, Poland; adam.okorski@uwm.edu.pl

* Correspondence: k.zalewski@uwm.edu.pl

\begin{abstract}
Ten willow cultivars grown in experimental plots were evaluated for performance, attractiveness to foragers, and the content and composition of soluble carbohydrates. The survival of willow cuttings in a thicket and in browse plots differed subject to cultivar, soil quality, and soil moisture content. The number of stump sprouts varied considerably, from 1.1 shoots in the weakest soils in Słonin, Poland, to 3.43 in the plot in Czempin, Poland. Browse plots were established in 2017. They were cut, and fencing was removed in early spring of 2019 . Young shoots $(10 \mathrm{~cm}$ shoot tip with buds, preferably eaten by animals) were sampled for analyses of soluble carbohydrates as potential attractors for foraging cervids. All willow cultivars contained the same soluble carbohydrates: glucose, fructose, galactose, sucrose, myo-inositol, galactinol, and raffinose. Total carbohydrate content ranged from 21.31 (S. amygdalina 1045) to $69.37 \mathrm{mg} / \mathrm{g}^{-1} \mathrm{DM}$ (dry matter) (S. purpurea). Glucose was the predominant soluble sugar in the shoots of all willow cultivars, excluding $S$. viminalis. The fructose content of the shoots was approximately twice lower than their glucose content in all willow cultivars. Smaller differences were observed in the content of myo-inositol, which ranged from 4.61 (S. amygdalina 1045) to $8.26 \mathrm{mg} / \mathrm{g}^{-1} \mathrm{DM}$ (S. fragilis cv. Kamon/Resko). The phloem of all willow species contained small quantities of galactinol and trace amounts of raffinose. Weak negative correlations were noted between total carbohydrate content, the content of glucose, fructose, and galactose vs. the attractiveness of willow shoots to foraging cervids. The remaining carbohydrates that occurred in smaller quantities in willow shoots were not correlated with their attractiveness to cervids.
\end{abstract}

Keywords: willow browse; soluble carbohydrates; browsing damage; cervids; gas chromatography

\section{Introduction}

Animals, including wild animals, are guided by the senses of smell and taste when selecting food [1]. The taste and aroma of potential food sources play a secondary role only in extreme situations, such as drought, deep snow cover, or the risk of hunger. Such extreme conditions persisted in Poland in the winters of 1962/63, 1978/79, 1986/87, and 2005/06, when roe deer, red deer, elk, as well as hares foraged on the young and green plant parts protruding above the deep snow cover. In those years, animals caused considerable damage to young forests and nurseries of forests, orchards, and ornamental trees and shrubs. Cervids also cause considerable browsing damage in years with less 
severe weather conditions, which forces forest managers to implement costly protective measures. In 2018, the total area affected by the foraging and browsing behavior of game animals, including red deer, fallow deer, roe deer, wild boars, and hares, in Poland was estimated at 56,300 ha, including 27,500 ha of agricultural land, 21,500 ha of young forests, and 7300 ha of mature forests. According to State Forests data [2], around $€ 44.8$ million was spent on protecting forests against foraging animals in 2019. Chemical and mechanical protection of seedlings and fencing generate the highest costs. In 2018, seedlings were protected in a total area of 91,500 ha, and 22,600 ha of forest nurseries were fenced. In Germany, $€ 11$ million was spent on forest nurseries and forest protection, of which $€ 3.2$ was dedicated to combating woodworm infestations. Considerable funds are also allocated to the protection of young forests against wild animals [3].

European foresters and hunters have long expressed an interest in experiments where alternative food sources for cervids, including mixed willow, sycamore, beech, oak, and linden stands, as well as pure willow stands, are grown in food plots, unused forest enclaves, browse plots, and on fallow land by forest and orchard nurseries [4]. The cultivation of willow browse is relatively problem-free. Willows (genus Salix) can be planted in a wide variety of soils, but only selected cultivars, such as $S$. alba cv. Tristis, $S$. integra cv. Hakuro Nishiki, S. purpurea cv. Gracilis, S. purpurea cv. Nana, or other cultivars of S. purpurea perform well on sandy and dry soils $[5,6]$. S. acutifolia is the most droughtresistant cultivar that is used to stabilize sand dunes on the Baltic coast and in the Błedów desert in Poland $[7,8]$. However, its attractiveness to foraging animals has never been studied. Some of the above willow cultivars (S. acutifolia) proved to be highly invasive, and their cultivation was discontinued.

The attractiveness of willow browse is a complex problem that is influenced by various factors. In a study performed by Drogoszewski and Wlazełko [9], only 6 out of 133 tested willow cultivars were not browsed by roe deer. Four of those were S. purpurea cultivars (out of the analyzed 18). Willow cultivars that are not attractive to foraging animals usually contain bitter inorganic salts, tannins, salicin, alkaloids, and other phenols in the leaves and bark. It is also possible that wild animals are able to detect the presence of substances with medicinal properties in willow shoots $[10,11]$. On the other hand, plants contain attractants such as complex carbohydrates-starches, soluble sugars, vitamins, mineral salts with essential macronutrients and micronutrients, proteins, fat, and fiber. Not all animal species have a preference for the same plant substances. For example, aspartame, an artificial sweetener composed of two amino acids, tastes sweet to humans, but not to mice [1]. Bears, monkeys, dogs, wild boars, squirrels, ants, and other animals have a preference for sweet foods. Cervids' preferences for sweet-tasting foods have never been investigated, and the extent to which the chemical composition of trees and shrubs contributes to their attractiveness to wild animals remains unknown. On the other hand, getting to know the preferences of cervids with regard to the feeding attractiveness to various species, varieties, or clones of willow might be for them an indicator of the quantity and quality of substances contained in these plants. In view of the above, the aim of this study was to determine the content and composition of soluble carbohydrates in ten willow cultivars, and to evaluate their attractiveness to cervids.

\section{Materials and Methods}

\subsection{Experimental Plots}

In the spring of 2015, a willow thicket was established at the research station of the Polish Hunting Association in Czempin near Poznań, Poland. Willow cuttings were obtained from experimental nurseries in the Resko Forest Inspectorate (Region of Western Pomerania), and field-plots established at experimental stations (owned by the University of Warmia and Mazury in Olsztyn) in Obory, Poland (Region of Pomerania), and Bałdy, Poland (Region of Warmia and Mazury) (Table 1). Weeds were removed only mechanically and manually in July of 2015 and 2016. The survival of willow cuttings and shoot growth were evaluated in September 2015. The willow thicket in Czempin, Poland, was cut 
in the spring of 2016 and in early March 2017, and one-year-old shoots were used to establish three experimental browse plots near Grzybno, Poland (X: 482950.30; Y: 351700.42), Bieczyny, Poland (X: 484298.21; Y: 345303.04), and Słonin, Poland (X: 475485.18; Y: 344974.35) (Figure 1).

Willow varieties, breeding lines, and cultivars (collectively referred to as cultivars in the study) for the establishment of the willow thicket at the research station in Czempin, Poland, were selected based on their availability and the results of previous research on willow browse $[3,8,9]$. Based on the numerous studies investigating willow browse and the medicinal properties of willows, S. purpurea 1126, which was completely or partly ignored by wild animals during previous observations, was introduced as the control cultivar on account of its high salicin content $[8,9,12-15]$.

Table 1. Cultivar designations used later in the work in the tables and figures.

\begin{tabular}{|c|c|c|}
\hline Name of the Cultivar & Willow Species & Cultivar No. Used in Tables and Figures \\
\hline Resko Forest Inspektorate & S. amygdalina cv. Dunajec & 1 \\
\hline Resko Forest Inspektorate & S. amygdalina cv. Krakowianka & 2 \\
\hline $\begin{array}{l}\text { Experimental Station of University of Warmia } \\
\text { and Mazury in Obory }\end{array}$ & S. amygdalina 1045 & 3 \\
\hline $\begin{array}{l}\text { Experimental Station of University of Warmia } \\
\text { and Mazury in Obory }\end{array}$ & S. amygdalina 1102 & 4 \\
\hline $\begin{array}{l}\text { Experimental Station of University of Warmia } \\
\text { and Mazury in Obory }\end{array}$ & S. amygdalina 1036 & 5 \\
\hline $\begin{array}{l}\text { Experimental Station of University of Warmia } \\
\text { and Mazury in Obory }\end{array}$ & S. fragilis cv. Kamon & 6 \\
\hline Resko Forest Inspektorate & S. fragilis cv. Kamon & 7 \\
\hline $\begin{array}{l}\text { Experimental Station of University of Warmia } \\
\text { and Mazury in Bałdy }\end{array}$ & S. laurina $220 / 225$ & 8 \\
\hline $\begin{array}{l}\text { Experimental Station of University of Warmia } \\
\text { and Mazury in Bałdy }\end{array}$ & S. pentederana & 9 \\
\hline $\begin{array}{l}\text { Experimental Station of University of Warmia } \\
\text { and Mazury in Obory }\end{array}$ & S. purpurea 1126 & 10 \\
\hline
\end{tabular}

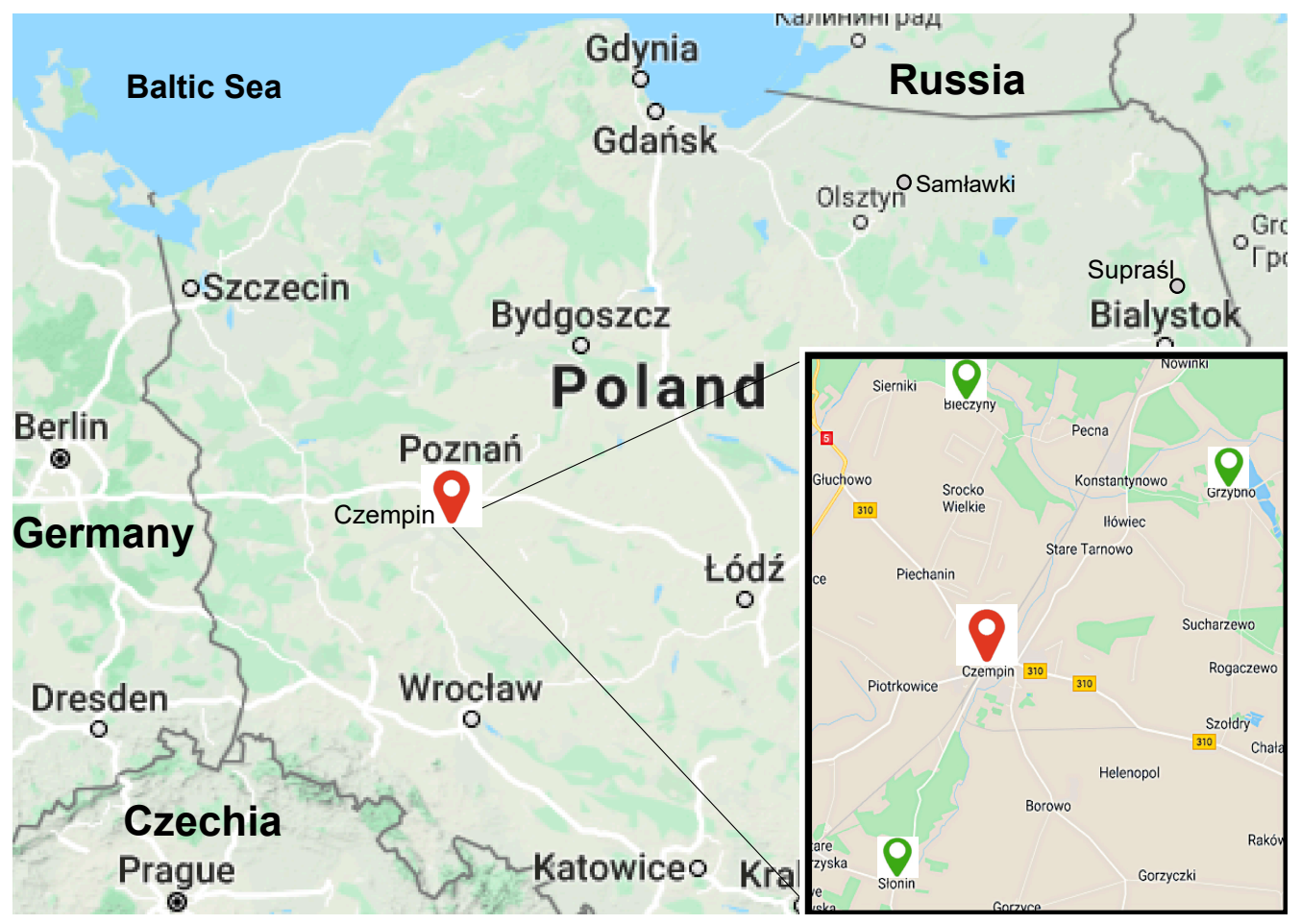

Figure 1. Location of the experimental willow plots. 
Willows were planted in 2017, with inter-row spacing of $75 \mathrm{~cm}$ and intra-row spacing of $30 \mathrm{~cm}$. The area of the plot established in 2015 in Czempin was $2500 \mathrm{~m}^{2}$, where 5045 cuttings were planted. Respectively, the plots established in spring 2018: Bieczyny-800 $\mathrm{m}^{2}$ and 2800 cuttings; Grzybno- $870 \mathrm{~m}^{2}$ and 3080 cuttings; and Słonin-920 $\mathrm{m}^{2}$ and 3430 cuttings. The number of individual cultivars planted in a plot depended on their availability on the market in 2015 and was as follows (according to the numbering from Table 1): Cultivar No. 1-50; 2-1000; 3-1000; 4-1000; 5-1000; 6-110; 7-400; 8-45; 9-40; and 10-400 cuttings. Each of the cultivars numbered 2, 3, 4, 5, 7, and 10 were randomly planted in several rows. Thus, e.g., S. amygdalina cv. Krakowianka was planted in 5 rows separated by other cultivars. The planting of cuttings on the mother plot was completely random, as well as on the occlusal plots established two years later.

Browse plots were fenced with wire mesh to a height of $2.5 \mathrm{~m}$, for two years, and weeds were removed mechanically each year in July. The performance of the willow thicket was evaluated in September of 2017 and 2019, and the survival of the willow cuttings in browse plots was evaluated in September 2019.

\subsection{Browsing Damage Assessment}

In the fall of 2017 and 2019, the damage caused by wild animals in browse plots after fencing had been removed was assessed on a 5-point scale proposed by Bukiewicz [12], with some modifications, where 1 point-absence of damage, no traces of shoot, bud or leaf browsing; coefficient for calculating browsing damage- $0.00(0 \%)$; 2 points-minor damage to selected shrubs, with full recovery; coefficient for calculating browsing damage- 0.05 (5\%); 3 points-moderate damage to the top part of the main shoot or side shoots; signs of foliage browsing; bark stripping on short stem segments; absence of terminal buds, which can inhibit shoot growth and weaken willow shrubs; coefficient for calculating browsing damage-0.15 (15\%); 4 points—considerable damage to the main shoot, side shoots and buds; complete or partial loss of foliage; damage to stump sprouts; bark stripping on more than half of stem length, which can significantly inhibit shrub growth and lead to tissue necrosis in stumps under unfavorable conditions; coefficient for calculating browsing damage - $0.50(50 \%)$; and 5 points—absence of shoots, damaged and necrotized shoots; coefficient for calculating browsing damage-1.00 (100\%).

When assessing the browsing damage, five repetitions were made, each with 20 consecutive seedlings in a row. For cultivars with less than 200 plants per plot (cultivars No. 1, 6, 7, and 8), all seedlings were assessed.

\subsection{Analysis of the Content of Soluble Carbohydrates}

At the end of July 2017, ten one-year old shoots with leaves grown from two-year-old stool were obtained from each willow cultivar (three replicates) in the thicket in Czempin, Poland, and the harvested material was analyzed for the content of soluble carbohydrates. A total of 30 samples of $10 \mathrm{~cm}$ tops of one-year-old shoots were analyzed. Each sample of 10 stems was analyzed separately. Since S. pentederana and S. amygdalina cv. Krakowianka did not survive in the three-year-old thicket in Czempin, Poland, shoot samples from these cultivars were obtained from the experimental plots in Bałdy, Poland.

Shoot samples (10 cm tips with the buds of one-year old shoots) were weighed, frozen in liquid nitrogen, and lyophilized. Dry tissues were crushed in a mixer mill MM200 (Retsch, Katowice, Poland). Soluble carbohydrates were extracted from $40 \mathrm{mg}$ of dry material using $800 \mu \mathrm{L}$ of $50 \%$ ethanol (containing $100 \mu \mathrm{g}$ of xylitol, as an internal standard) and analyzed by gas chromatography method on the ZEBRON ZB-1 capillary column (Phenomenex, CA, USA), as described previously [16]. The carbohydrate content was calculated using the internal standard method. Standards of carbohydrates (xylitol, fructose, galactose, glucose, myo-inositol, sucrose, galactinol, raffinose, 1-kestose, stachyose, and verbascose) were purchased from Sigma (USA). The amount of unknown carbohydrates with retention times (Rt) of 6.52 and 7.39 was calculated based on the nearest known standards (1-kestose and stachyose, respectively). 


\subsection{Experiment with Farmed Red Deer and Fallow Deer}

In January 2020, twenty one-year-old shoots grown from leafless three-year-old stool were harvested from each willow cultivar (in three replicates) and fed to European red deer at the research station in Czempin, Poland, and red deer and fallow deer at the research station of the Polish Academy of Sciences in Kosewo Górne, Poland. Both deer species were kept separately. The shoots came from the plot located in Bieczyny, Poland. One hundred and twenty shoots were cut from each cultivar and divided into 6 bunches, three for each town (Czempin and Kosewo Górne). All bunches from all cultivars were collected at the same time and their fresh weight was determined. All bunches were tied to the fence where the animals were kept. The decrease in shoot mass caused by browsing was determined after 3 days. The degree of browsing damage was determined after the loss of fresh weight. All tests were subjected to the same atmospheric conditions.

The analysis of correlations between the relative sweetness of the total carbohydrates and severity of browsing damage on willow shoots was performed. The sweetness of the individual sugars and total carbohydrates was determined by multiplying the sugar content of the willow tissues ( $\mathrm{mg} \mathrm{g}^{-1} \mathrm{DM}$ ) by the relative sweetness (RS) indicators (Table 2) given in the literature. Galactinol and sucrose are non-reducing disaccharides because both galactose and myo-inositol have $\alpha$-(1-1)-glycosidic bonds; therefore, an RS index of 0.6 was adopted for galactinol [17-19].

Table 2. Sweetness of the selected carbohydrates relative to sucrose (see the source in the reference list).

\begin{tabular}{cccc}
\hline Sugar & {$[20]$} & {$[21]$} & Average \\
\hline Glucose-fructose & 100 & 100 & 100 \\
syrup/relative sweetness & 100 & 100 & 100 \\
Sucrose & 173 & 180 & 176.50 \\
Fructose & 74 & 75 & 74.50 \\
Glucose & 32.1 & 32 & 32.05 \\
Galactose & 32 & 30 & 31 \\
Maltose & - & 30 & 30 \\
Mannose & 16 & 25 & 20.5 \\
Lactose & 10 & - & 10 \\
Raffinose & 50 & - & 50 \\
Myo-inositol & 60 & - & 60 \\
Galactinol & & & \\
\hline
\end{tabular}

\subsection{Statistical Analysis}

The results were processed statistically in the Statistica program (v. 13.1, Dell Inc., Tulsa, OK, USA). The least significant difference was calculated at $p \leq 0.01$, with the use of Tukey's test. The relationships between the carbohydrate content of the shoots and the severity of browsing damage caused by cervids were determined based on the calculated values of Pearson's linear correlation coefficient $\mathrm{R}(p \leq 0.05 ; p \leq 0.01)$.

\section{Results}

\subsection{Soil Analysis}

Soil samples for laboratory analyses were collected from the experimental plots where the evaluated willow cultivars were grown. The soil acidity $(\mathrm{KCl})$, content of organic carbon, total nitrogen, and major macronutrients $(\mathrm{P}, \mathrm{K}$, and $\mathrm{Mg}$ ) were determined in $100 \mathrm{~g}$ soil samples (Table 3). Soil samples from the willow thicket in Czempin, Poland, were acidic, moderately abundant in phosphorus, highly abundant in potassium, and moderately abundant in magnesium. The content of total organic carbon was determined at $1.15 \%$, which, when converted to humus content $(1.15 \times 1.7=1.96)$, is a satisfactory (average) result for slightly loamy sand. The experimental plot in Słonin, Poland, was established on slightly alkaline soil with a moderate phosphorus and potassium content, 
which was highly permeable due to an $80 \mathrm{~cm}$-deep layer of loose sand. The experimental plots were established in the following types of habitats: Czempin, Poland-fresh forest established on former agricultural land (Category 2); Bieczyny, Poland-dehydrated humid forest established on former agricultural land (Category 2); Grzybno, Poland-fresh mixed coniferous forest with low groundwater levels (Category 1); Słonin, Poland-fresh forest with very low groundwater levels (Category 1 ). Categories 1 and 2 characterize the degree of moisture in the soil in which the forest grows, where Category 1 indicates poor soil irrigation and Category 2 good soil irrigation.

Table 3. Soil parameters in the experimental willow plots.

\begin{tabular}{|c|c|c|c|c|c|c|c|}
\hline \multirow[b]{2}{*}{ Plot } & \multirow[b]{2}{*}{ Soil Type } & \multirow[b]{2}{*}{$\begin{array}{c}\mathrm{pH} \text { (in } \\
\mathrm{KCl})\end{array}$} & \multicolumn{5}{|c|}{ Soil Content (Average of Three Replicates) } \\
\hline & & & $\begin{array}{c}\mathrm{P}_{2} \mathrm{O}_{5} \\
\text { (mg/100 g } \\
\text { of Soil) }\end{array}$ & $\begin{array}{c}\mathrm{K}_{2} \mathrm{O} \\
\text { (mg/100 g } \\
\text { of Soil) }\end{array}$ & $\begin{array}{c}\mathrm{Mg} \\
\text { (mg/100 g } \\
\text { of Soil) }\end{array}$ & $\begin{array}{c}\text { N Total } \\
(\%)\end{array}$ & $\begin{array}{c}\text { C Organic } \\
(\%)\end{array}$ \\
\hline Czempin & $\begin{array}{l}\text { Loamy } \\
\text { sand }\end{array}$ & 4.98 & 14.8 & 14.0 & 3.6 & 0.086 & 1.98 \\
\hline Bieczyny & $\begin{array}{l}\text { Sandy } \\
\text { loam } \\
\text { Slightly }\end{array}$ & 7.60 & 7.3 & 7.44 & 4.6 & 0.35 & 1.62 \\
\hline Grzybno & $\begin{array}{c}\text { loamy } \\
\text { sand }\end{array}$ & 6.42 & 12.0 & 3.1 & 1.9 & 0.07 & 1.02 \\
\hline Słońsk & $\begin{array}{l}\text { Slightly } \\
\text { loamy } \\
\text { sand }\end{array}$ & 7.31 & 13.8 & 8.2 & 2.1 & 0.098 & 0.75 \\
\hline
\end{tabular}

\subsection{Willow Performance (Survival)}

Willow survival in the first and third year of growth were high (above $60 \%$ ) in the thicket and in the experimental plots in Bieczyny and Grzybno, Poland (Figure 2). In Słonin, Poland (Figure 2D), the survival exceeded $80 \%$ in three cultivars only. Two years after establishment, numerous stumps were lost in all plots due to drought, and the highest losses were noted in Słonin, Poland (Figure 2D). Losses ranged from 80\% to 95\%, depending on the cultivar (applies to Cultivars No. 1, 2, 4, and 8). In 2017, 2018, and 2019, the Wielkopolska Region in Poland was affected by soil drought, which led to a massive loss of willow stumps in browse plots and partial losses in the thicket. Willow survival in the plots was evaluated for the second time in September in the third year of growth, whereas the thicket was assessed three times during the experiment. Browsing damage was most extensive in the experimental plot in Słonin, Poland, where willows were grown on sandy and highly permeable soil. S. laurina 220/225 (cv. No. 8) was nearly completely eliminated, and less than 5\% of the S. amygdalina 1102 (cv. No. 4), S. amygdalina cv. Dunajec (cv. No. 1), and S. amygdalina cv. Krakowianka (cv. No. 2) shrubs survived (Figure 2). In the browse plot in Grzybno, Poland, S. amygdalina cv. Dunajec (cv. No. 1) was infested with dock bugs (Coreus marginatus L.), which damaged nearly $80 \%$ of the leaves and developing buds. The above cultivar survived the infestation.

\subsection{Analysis of Shoot Browsing}

The quality of willow cultivars and the survival differed across the plots after fencing had been removed (Figure 3). Willow performance was largely influenced by the type of habitat, in particular in dry years. The plot in Słonin, Poland, was established on highly permeable soil of the lowest quality (classes IV-VI). In the north, the plot was bound by a fresh mixed forest and a fresh forest composed of pines, birches, and, sporadically, oaks, with a dense undergrowth of black cherry and hazel. Signs of foraging by fallow deer and roe deer (which permanently inhabited the region), as well as mouflons (which were periodically observed in the region) were noted (Figure 3).

In comparison with the remaining two plots, the plot in Bieczyny, Poland offered the optimal habitat for red deer and roe deer. The plot in Grzybno, Poland, was characterized by medium-quality soils, and it was visited mainly by roe deer. Signs of foraging and 
tracks of other animal species were observed sporadically after fencing had been removed. In the willow thicket, two cultivars (S. amygdalina cv. Krakowianka and S. pentederana) were also lost due to drought, but only in the fourth and fifth year of growth (Figure 2).

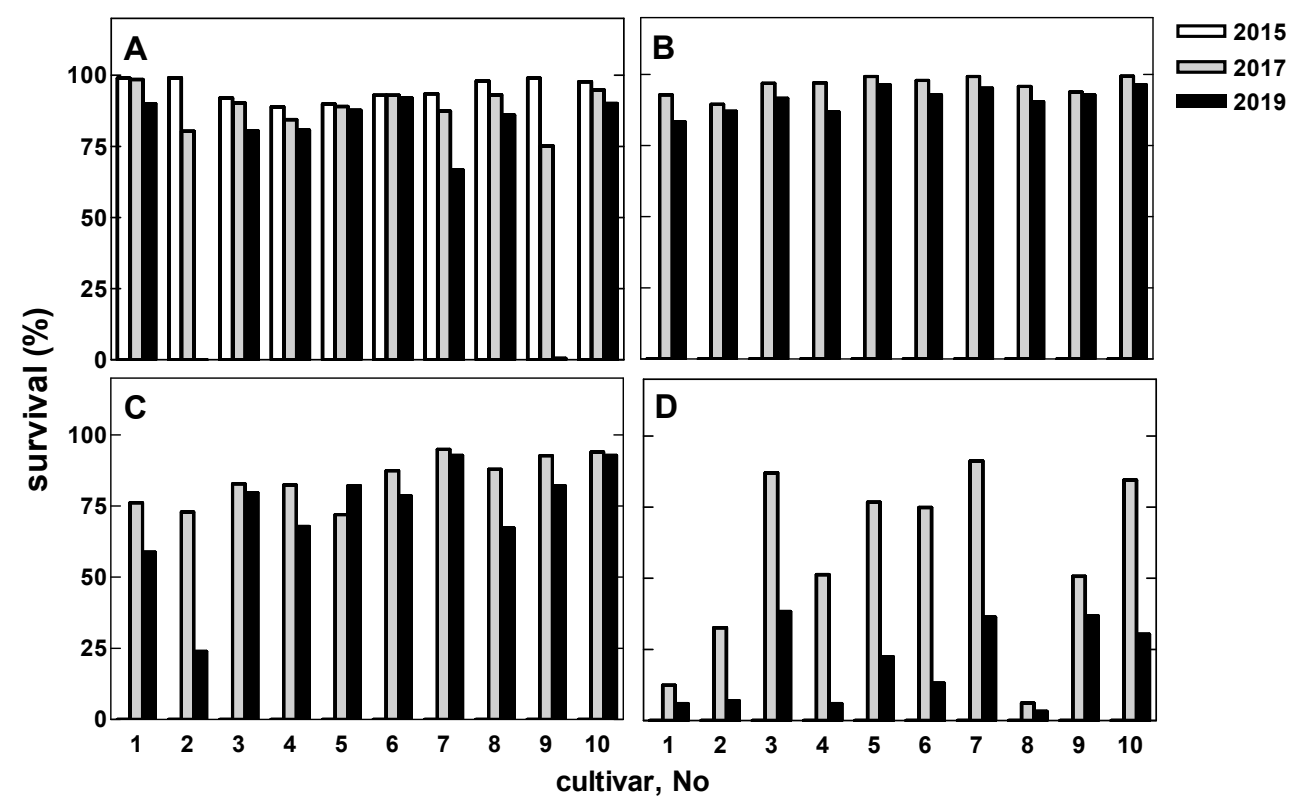

Figure 2. Willow survival (\%) in the experimental plots in the first (2015), second (2017), and third (2019) year of vegetation in (A) Czempiń-backwoods; (B) Bieczyny; (C) Grzybno; and (D) Słonin. All stumps were counted. For the cultivar explanation, see Table 1.

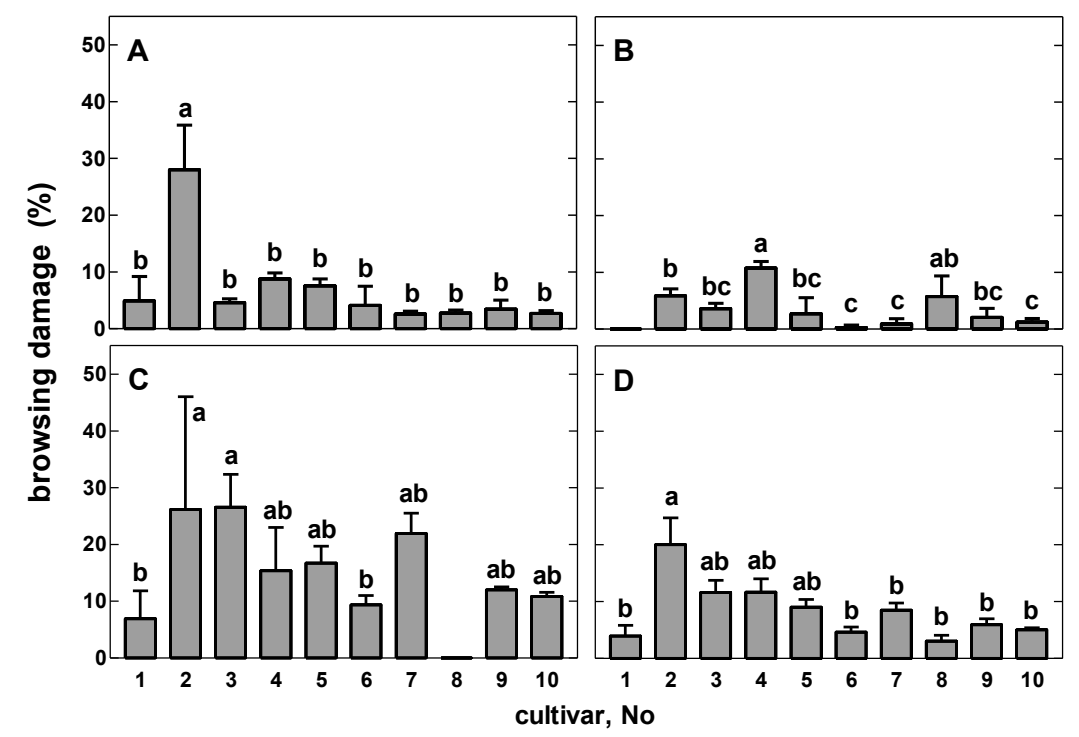

Figure 3. Severity of browsing damage to the analyzed willows cultivated in (A) Bieczyny; (B) Grzybno; and (C) Słonin. The mean values for three localization (A-C) are shown in box (D). Data were processed by analysis of variance. Bars with the same letters did not differ significantly $(p \leq 0.01)$ in Tukey's test. For the cultivar explanation, see Table 1.

\subsection{Content of Soluble Carbohydrates}

The shoots of all analyzed willow cultivars contained the same soluble carbohydrates: glucose, fructose, sucrose, myo-inositol, galactinol, and raffinose. Total carbohydrate content ranged from 21.31 (S. amygdalina 1045) to $69.37 \mathrm{mg} / \mathrm{g}^{-1} \mathrm{DM}$ (S. purpurea).

Glucose was the predominant sugar in most cultivars, accounting for more than $50 \%$ of the identified soluble carbohydrates (Figure 4). Glucose levels were highest in S. purpurea 
(45.93 mg/g $\left.{ }^{-1} \mathrm{DM}\right)$, S. pentaderana $\left(35.08 \mathrm{mg} / \mathrm{g}^{-1} \mathrm{DM}\right)$, and S. fragilis $\left(29.19 \mathrm{mg} / \mathrm{g}^{-1} \mathrm{DM}\right.$ on average), and lowest in S. amygdalina 1045 (11.61 mg/g ${ }^{-1} \mathrm{DM}$ on average). The fructose content of the shoots was approximately two-fold lower than their glucose content in all willow cultivars, whereas the galactose content was approximately 10 -fold lower than the fructose content. Most cultivars contained even less sucrose than galactose, excluding S. purpurea $1126\left(0.55 \mathrm{mg} / \mathrm{g}^{-1} \mathrm{DM}\right)$. Smaller differences were noted in the content of myo-inositol, which ranged from 4.61 (S. amigdalina 1045) to $8.26 \mathrm{mg} / \mathrm{g}^{-1} \mathrm{DM}$ (S. fragilis cv. Kamon/Resko). The phloem of all willow species also contained small quantities of galactinol $\left(0.07-0.55 \mathrm{mg} / \mathrm{g}^{-1} \mathrm{DM}\right)$ and trace amounts of raffinose $\left(0-0.13 \mathrm{mg} / \mathrm{g}^{-1} \mathrm{DM}\right)$. Raffinose was not detected in Cultivars No. 2, 3, 4, and 6 (Figure 4).
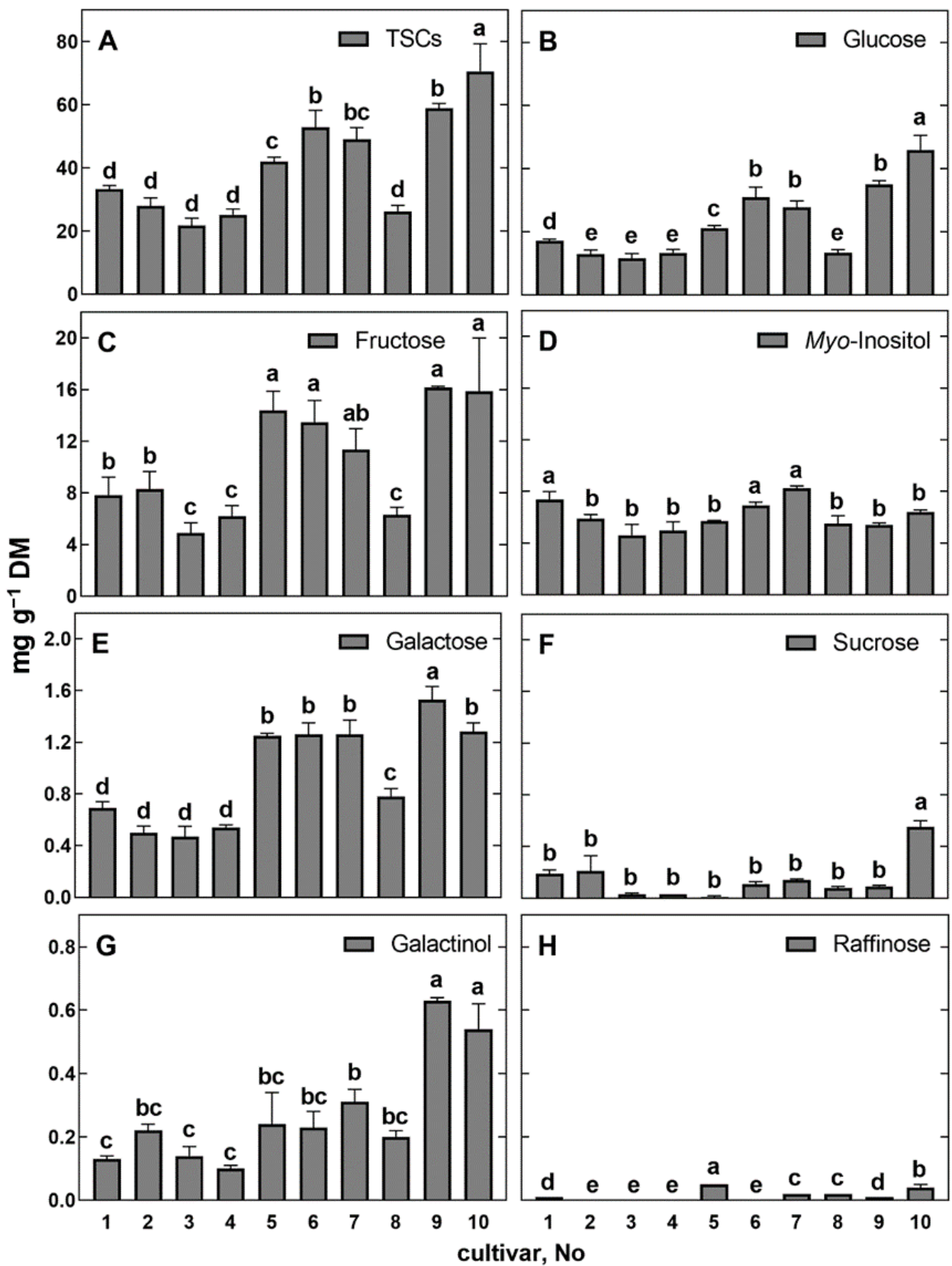

Figure 4. The content of soluble carbohydrates in the shoots of the analyzed willow cultivars: (A) total soluble carbohydrates; (B) glucose; (C) fructose; (D) myo-inositol; (E) galactose; (F) sucrose; (G) galactinol; and (H) raffinose. Values marked with different letters (a to e) are significantly different at $p \leq 0.01$. For the cultivar explanation, see Table 1 . 


\subsection{Shoot Sweetness and Browsing Damage}

The extent to which browsing damage was correlated with the sweetness of the evaluated willow cultivars was evaluated in a statistical analysis using Pearson's linear correlation coefficient $\mathrm{R}(p \leq 0.05 ; p \leq 0.01)$.

The analysis revealed weak negative correlations between the RS of total carbohydrates $(R=-0.28)$ (Figure $5 A)$, the $R S$ of glucose $(R=-0.26)$ (Figure $5 B)$, and the $R S$ of fructose $(R=-0.27)$ (Figure $5 C$ ) vs. the severity of browsing damage on willow shoots. No such correlations were observed for the remaining carbohydrates that were less abundant in willow tissues (Figure 5D-H).

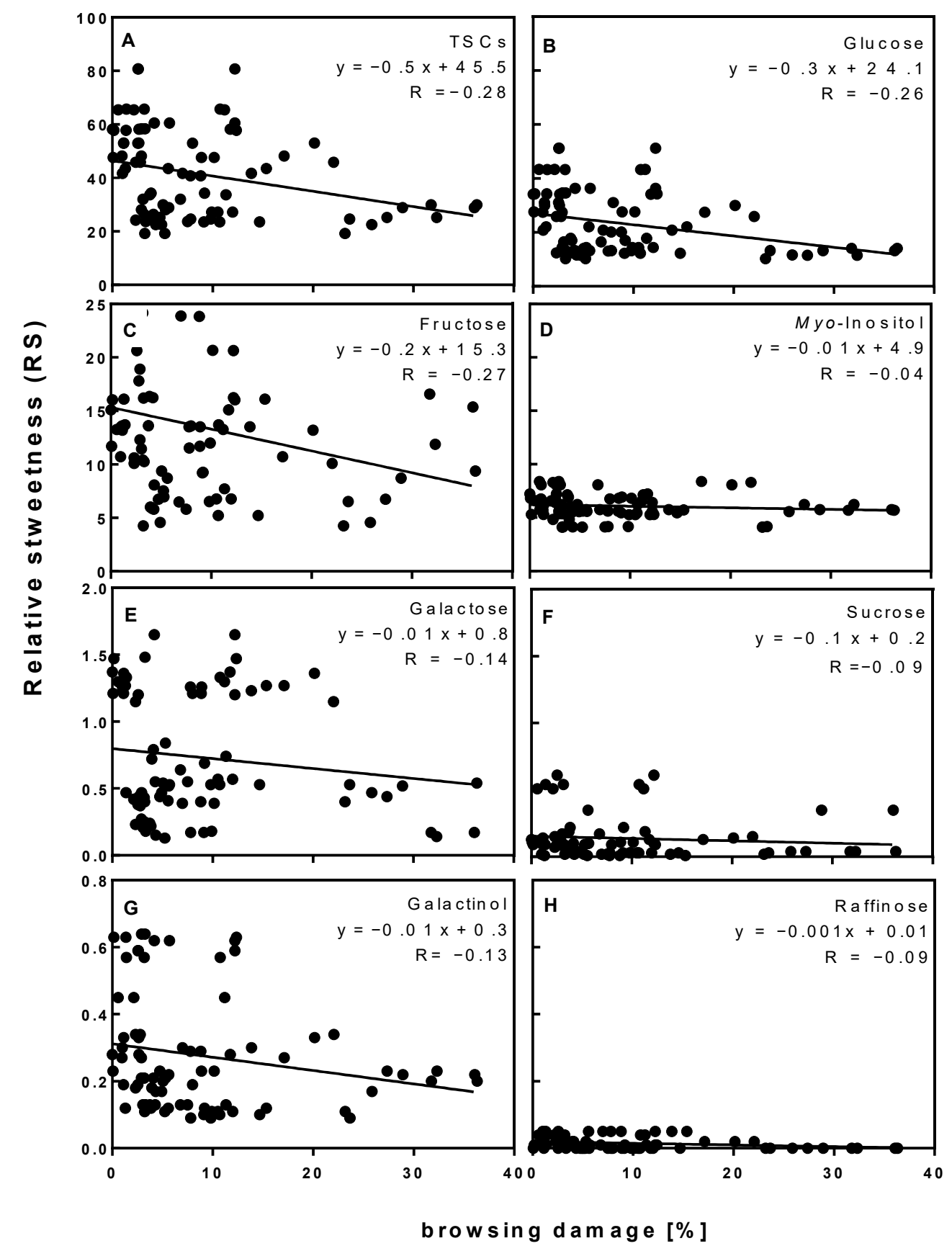

Figure 5. The analysis of correlations between the relative sweetness of the total carbohydrates and severity of browsing damage on willow shoots: (A) total soluble carbohydrates; (B) glucose; (C) fructose; (D) myo-inositol; (E) galactose; (F) sucrose; (G) galactinol; and (H) raffinose. R-Pearson's linear correlation coefficient. 
Farmed red deer and fallow deer did not express particular interest in one-year-old shoots harvested from the studied willow cultivars (Table 4). The animals had the greatest preference for S. cordata and S. laurina (red deer), as well as S. cordata, S. amygdalina cv. Dunajec, S. amygdalina cv. Krakowianka, and S. laurina (fallow deer), but intensive foraging behavior was not observed. It should also be noted that the content of soluble sugars in overwintered shoots increased by $52.3 \%$ relative to the shoots harvested in the middle of the growing season (July). An analysis of $S$. cordata tissue samples also demonstrated changes in the proportions of soluble carbohydrates. The content of fructose decreased, whereas sucrose levels increased between July and January (Table 5).

Red deer expressed varied interest in willow shoots, which generally differed between the studied locations. The animals in both stations had a greater preference for S. cordata, but fallow deer were less discriminating in their choice of willow cultivar than red deer (Table 4).

Table 4. The attractiveness of the analyzed willow cultivars to red deer and fallow deer at the research station of the Polish Hunting Association in Czempin and the Cervid Farm of the Polish Academy of Sciences in Kosewo Górne, based on the average decrease in shoot mass (\%) of duplicate measurements.

\begin{tabular}{cccc}
\hline Cultivar No. & $\begin{array}{c}\text { Deer } \\
\text { Czempiń }\end{array}$ & $\begin{array}{c}\text { Deer } \\
\text { Kosewo G. }\end{array}$ & $\begin{array}{c}\text { Fallow Deer } \\
\text { Kosewo G. }\end{array}$ \\
\hline 1 & 10.76 & 0 & 5.94 \\
2 & 3.91 & 0 & 6.44 \\
3 & 4.48 & 0 & 3.00 \\
4 & 18.50 & 1.02 & 4.25 \\
5 & 14.49 & 13.54 & 8.90 \\
6 & 8.58 & 0 & 6.39 \\
7 & 8.99 & 0 & 2.18 \\
8 & 18.32 & 6.92 & 4.80 \\
9 & 16.76 & 0 & 0.07 \\
10 & 4.49 & 0 & 4.72 \\
\hline
\end{tabular}

Table 5. Average sugar content $\left(\mathrm{mg} / \mathrm{g}^{-1} \mathrm{DM}\right)$ of Salix cordata shoots harvested in July and January ( $n=3$ for each species and sugar) with the standard deviation.

\begin{tabular}{ccc}
\hline & \multicolumn{2}{c}{ Cultivar } \\
\hline & $\begin{array}{c}\text { S. cordata } \text { UWM 1036 } \\
\text { (July 2019) }\end{array}$ & $\begin{array}{c}\text { S. cordata UWM 1036 } \\
\text { (January 2020) }\end{array}$ \\
\hline Fructose & $14.37 \pm 1.50$ & $2.92 \pm 0.03$ \\
Galactose & $1.25 \pm 0.02$ & 0.00 \\
Glucose & $21.00 \pm 1.02$ & $2.04 \pm 0.01$ \\
Myo-inositol & $5.70 \pm 0.07$ & $0.43 \pm 0.01$ \\
Sucrose & $0.01 \pm 0.01$ & $37.85 \pm 0.48$ \\
Galactionol & $0.24 \pm 0.10$ & 0.00 \\
Raffinose & $0.05 \pm 0.00$ & $14.18 \pm 0.68$ \\
Stachyose & 0.00 & $5.28 \pm 0.20$ \\
Verbascose & 0.00 & $0.34 \pm 0.02$ \\
Total sugars & $41.37 \pm 2.40$ & $63.03 \pm 1.25$ \\
\hline
\end{tabular}

\section{Discussion}

Human interventions in reducing damage to forests, such as the use of fencing and chemicals, should be minimized or completely eliminated in order to preserve the biodiversity of natural habitats. Artificial structures and chemicals should be replaced with trees and shrubs that, at least partially, protect valuable crops from damage and reduce crop losses to an economically acceptable level. 
The attractiveness of willow shoots to herbivores is determined by various factors, in particular the chemical composition of willow cultivars and their growth stage. The survival and growth rates of willows and, to a certain extent, the chemical composition of the shoots is correlated with the soil quality and soil moisture content (Figures 2 and 4; Table 3). In the present study, the willow thicket and the experimental plots differed significantly in soil parameters. The soil in Słonin, Poland, was susceptible to dehydration due to low water-holding capacity and the absence of capillary action. In this experimental plot, the performance of willows was completely dependent on precipitation, in particular in the dry years 2017-2019. The survival was very low in the first year after planting, and only $21.7 \%$ of the planted cuttings survived the dry years 2018 and 2019. S. laurina was the least resistant to drought (only $3.2 \%$ of stumps survived), whereas $S$. amygdalina 1045, S. amygdalina cv. Kamon/Resko, and S. pantederana were least susceptible to water deficit (50.1\% of stumps survived). The results of the study clearly demonstrate that soil parameters and habitat type significantly influence root establishment and sprouting.

The content and composition of soluble carbohydrates in willows remain insufficiently investigated. Aliferis et al. [22] identified glucose, fructose, galactose, myo-inositol, trehalose, and sugar alcohols-arabitol, mannitol, and glycosides-in fully developed leaves of 6- to 8-week-old S. purpurea L. (cv Fish Creek) plants. Sucrose, galactinol, and raffinose were not detected. Similar to this study, the predominant sugars in the leaves of hydroponically grown S. viminalis were sucrose, glucose, and fructose (Figure 4) [23]. However, the sucrose, glucose, and fructose concentrations were more than twice higher in the cited experiment than in this study. In the leaves harvested from the top shoots of two $S$. viminalis $\times S$. schwerinii hybrid cultivars grown in a field, the glucose and sucrose concentrations were similar and significantly higher than the fructose levels [24]. The sugar concentrations were lower in older than in younger plants, and similar observations were made in the hybrid poplars Populus deltoides $\times$ P. nigra [25]. Corol et al. [24] also identified small quantities of raffinose and stachyose in the leaves of $S$. viminalis $\times S$. schwerinie. In the present study, raffinose (but not stachyose) was detected in most willow cultivars (excluding S. amigdalina), and it was most abundant in $S$. cordata $\left(0.05 \mathrm{mg} \mathrm{g}^{-1} \mathrm{DM}\right)$. The presence of galactinol (a precursor of raffinose and its higher homologs) in all willow species indicates this oligosaccharide is synthesized in tissues in response to water and temperature stress (drought) [26]. Unlike glucose and fructose, galactinol does not appear to increase the sweetness of willow shoots, due to its low content. However, galactinol acts as a donor of the galactosyl groups for other sugars, and therefore its presence can enhance sweetness [27]. The statistical analysis revealed significant differences in the concentrations of individual soluble carbohydrates and in the total sugar content between the evaluated willow cultivars. The differences in the content of soluble carbohydrates between the cultivars studied here could be associated with the rate of the plant's growth, and/or rate of shoot tip elongation. In our study, the much higher concentration of monosaccharides (glucose and fructose) (Figure 5B,C) than that of sucrose, found for all cultivars, could be an indirect confirmation of the role of the shoot tips as the major sink tissues of willow plants, as in other species [28]. Sucrose is the major photoassimilate distributed from the leaves (sources) to the sinks [29], where it is hydrolyzed (presumably by invertases) into monosaccharides and serving as the carbon and energy sources for fast-growing tissues.

According to research, sweet taste perception differs considerably among animal species [30]. Foods rich in soluble carbohydrates are attractive to many animals and promote foraging behavior. The presence of sugars is responsible for sweet taste perception, but perceived sweetness can also be enhanced or reduced by phenols and other compounds. These compounds can exert a greater effect on sweetness in combination than alone.

In the current study, an experiment involving farmed red deer and fallow deer was carried out to determine whether the concentration of soluble sugars influences the attractiveness of willow shoots to cervids. One-year-old shoots of the analyzed willow cultivars harvested in mid-January were less attractive to the animals than the shoots harvested in spring and summer. Red deer and fallow deer had the greatest preference for $S$. cordata 
and S. laurina (signs of browsing damage were observed on up to $30 \%$ of the shoots). Sugar content could play a role in the foraging preferences of cervids because shoots harvested in January contained significantly more soluble carbohydrates (approx. $52 \%$ in S. cordata) than those harvested in late July. However, the statistical analysis revealed no significant correlations between the severity of browsing damage in spring and summer and the content of soluble sugars in the evaluated willow cultivars. These findings suggest that soluble carbohydrates do not act as typical attractants for red deer and fallow deer. Further research is needed to determine whether a sweet taste is not perceived by fallow deer and red deer due to the absence of the respective receptors [31], too low sugar concentrations in willow shoots, or the presence of other compounds, such as phenols, that mask the sweet taste of willow shoots.

\section{Conclusions}

The data presented in this work show that success in the cultivation of willow depends on the chosen cultivar and soil quality, especially its hydration. Young shoots of the analyzed cultivars contained from $2.1 \%$ to $6.9 \%$ soluble sugars, among which quantitatively dominated glucose. These sugars did not have a significant impact on the attractiveness of willows for cervids, which means that other chemical compounds are such a factor. It is possible that there are quantitative relationships between soluble sugars, phenolics, and other compounds that determine food attractiveness for cervids. Roe deer, fallow deer, and European deer do not have identical preferences for all willow cultivars, but they are those that are eaten very willingly by all of these animal species. This fact should be taken into account when selecting species for established plantations.

Author Contributions: Conceptualization, K.Z. and M.B.; methodology, K.Z., L.B.L. and M.B.; software, M.B. and A.O.; validation, M.B. and K.Z.; formal analysis, M.B. and K.Z.; investigation, M.B.; resources, M.J.S.; data curation, M.B., A.O., M.J.S. and K.Z.; writing-original draft preparation, M.B.; writing-review and editing, K.Z., R.S.; visualization, A.O.; supervision, K.Z.; project administration, K.Z. and M.B.; funding acquisition, K.Z. and M.B. All authors have read and agreed to the published version of the manuscript.

Funding: This research was funded by the University of Warmia and Mazury in Olsztyn, grant number 12.610.012-110; and the Main Board of the Polish Hunting Association, grant number $1 / \mathrm{PZE} / 2016$.

Institutional Review Board Statement: Ethical review and approval were waived for this study because in the test system used, animals were fed with no additives or chemical modifications. The animals received food that occurs naturally in the environment, and the care of the animals was provided under the status of the Research Station of Polish Hunting Association in Czempin, Poland, where these animals were kept.

Informed Consent Statement: Not applicable.

Conflicts of Interest: The authors declare no conflict of interest. The funders had no role in the design of the study; in the collection, analyses, or interpretation of data; in the writing of the manuscript, or in the decision to publish the results.

\section{References}

1. Scott, K. Taste Recognition: Food for Thought. Neuron 2005, 48, 455-464. [CrossRef] [PubMed]

2. State Forests Poland Forests in Poland 2018; Milewski, W. (Ed.) The State Forests Information Centre: Warsaw, Poland, 2018; ISBN 978-83-65659-40-8.

3. Kokocki, C.; Kowalski, A. Growth and Survival of Some Species of "Forage" Willows in Forest and Non-Forest Habitats; [Wzrost i przeżywalność niektórych gatunków wierzb "paszowych" na siedliskach leśnych i nieleśnych.]; University of Life Sciences: Poznań, Poland, 2012.

4. Klocek, A.; Hycza, T.; Jodłowski, K.; Kalinowski, M.; Kołakowski, B.; Szmidla, H.; Zachara, T. Forest Research Institute Bulletin No 1/2018. From the Forest World [Z leśnego świata] 2018, 102, 1-4.

5. Willow-Cultivation, Requirements, Varieties [Wierzba-Uprawa, Wymagania, Odmiany]. Available online: https://www. sadowniczy.pl/Wierzba-uprawa-wymagania-pielegnacja-cinfo-pol-624.html (accessed on 10 July 2020). 
6. Szczukowski, S.; Tworkowski, J.; Wiwart, M.; Przyborowski, J. Wicker (Salix sp.). Cultivation and Possibilities of Use; [Wiklina (Salix sp.). Uprawa i możliwości wykorzystania.]; Szczukowski, S., Ed.; Wydawnictwo ART: Olsztyn, Poland, $2002 ;$ ISBN 8387443409.

7. Rahmonov, O.; Szczypek, T.; Wach, J. The Blendow desert (Pustynia Błędowska) a unique phenomenon of the Polish landscape. Ann. Geogr. 2006, 39, 34-36.

8. Wiaderek, I.; Waliszewska, B. Selected mechanical properties of one-year old twigs of Salix acutifolia. Ann. Warsaw Univ. Life Sci. SGGW. For. Wood Technol. 2010, 72, 427-432.

9. Drogoszewski, B.; Wlazełko, M. The Trial of Determining the Food Preference of Roe Deer (Capreolus capreolus L.) in Relation of Some Willow Varieties; [Próba określania wybiórczości żerowej sarny (Caprcolus capreolus L.) w odniesieniu do nickiórych odmian wierzby]; PTPN: Poznań, Poland, 1980.

10. Krauze-Baranowska, M.; Szumowicz, E. Willow-The source of antiinflammatory and analgesic medicinal plants. Postępy Fitoter. 2004, 2, 77-86.

11. Niemiec, P.; Dubas, J.W. Forest Self-Service Pharmacies for Animals. [Leśne samoobsługowe apteki dla zwierzyny]. Brać Low. 2015, 10, 50-51.

12. Bukiewicz, H. Willow species useful for occlusal plots in forest fisheries. [Gatunki wierzb przydatne na poletka ogryzowozgryzowe w łowiskach leśnych.]. Zach. Porad. Low. 1963, 3, 7-8.

13. Kenstaviciene, P.; Nenortiene, P.; Kiliuviene, G.; Zevzikovas, A.; Lukosius, A.; Kazlauskiene, D. Application of high-performance liquid chromatography for research of salicin in bark of different varieties of Salix. Medicina 2009, 45, 644-651. [CrossRef]

14. Förster, N.; Ulrichs, C.; Zander, M.; Kätzel, R.; Mewis, I. Factors Influencing the Variability of Antioxidative Phenolic Glycosides in Salix Species. J. Agric. Food Chem. 2010, 58, 8205-8210. [CrossRef]

15. Sulima, P.; Krauze-Baranowska, M.; Przyborowski, J.A. Variations in the chemical composition and content of salicylic glycosides in the bark of Salix purpurea from natural locations and their significance for breeding. Fitoterapia 2017, 118, 118-125. [CrossRef]

16. Zalewski, K.; Lahuta, L.B.; Martysiak-Żurowska, D.; Okorski, A.; Nitkiewicz, B.; Zielonka, Ł. Effect of Exogenous Application of Methyl Jasmonate on the Lipid and Carbohydrate Content and Composition of Winter Triticale (Triticosecale Wittm.) Grain and the Severity of Fungal Infections in Triticale Plants and Grain. J. Agric. Food Chem. 2019, 67, 5932-5939. [CrossRef] [PubMed]

17. Martínez-Villaluenga, C.; Frias, J.; Vidal-Valverde, C. Alpha-Galactosides: Antinutritional Factors or Functional Ingredients? Crit. Rev. Food Sci. Nutr. 2008, 48, 301-316. [CrossRef] [PubMed]

18. Crittenden, R.G.; Playne, M.J. Production, properties and applications of food-grade oligosaccharides. Trends Food Sci. Technol. 1996, 7, 353-361. [CrossRef]

19. The Importance of Myo-Inositol in Plants. Available online: https://www.lebanonturf.com/education-center/plantbiostimulants/the-importance-of-myo-inositol-in-plants (accessed on 10 June 2020).

20. Cichon, R.; Wadołowska, L. Carbohydrates. In Human Nutrition. Introduction to Nutrition Science; [Żywienie człowieka. Podstawy nauki o żywieniu]; Gawęcki, J., Ed.; Polish Scientific Publishers PWN: Warsaw, Poland, 2010; pp. 149-150.

21. Sweet Life of a Chemist [Słodkie Życie Chemika]. Available online: https://mlodytechnik.pl./eksperymenty-i-zadania-szkolne/ chemia/29068-slodkie-zyciechemika?highlight=WyJzXHUwMTQyb2R5Y3oiXQ (accessed on 10 July 2020).

22. Aliferis, K.A.; Chamoun, R.; Jabaji, S. Metabolic responses of willow (Salix purpurea L.) leaves to mycorrhization as revealed by mass spectrometry and 1H NMR spectroscopy metabolite profiling. Front. Plant Sci. 2015, 6. [CrossRef]

23. Gąsecka, M.; Mleczek, M.; Drzewiceka, K.; Magdziak, Z.; Rissmann, I.; Chadzinikolau, T.; Golinski, P. Physiological and morphological changes in Salix viminalis L. as a result of plant exposure to copper. J. Environ. Sci. Health Part A 2012, 47, 548-557. [CrossRef]

24. Corol, D.; Harflett, C.; Beale, M.; Ward, J. An Efficient High Throughput Metabotyping Platform for Screening of Biomass Willows. Metabolites 2014, 4, 946-976. [CrossRef]

25. Regier, N.; Streb, S.; Zeeman, S.C.; Frey, B. Seasonal changes in starch and sugar content of poplar (Populus deltoides x nigra cv. Dorskamp) and the impact of stem girdling on carbohydrate allocation to roots. Tree Physiol. 2010, 30, 979-987. [CrossRef]

26. ElSayed, A.I.; Rafudeen, M.S.; Golldack, D. Physiological aspects of raffinose family oligosaccharides in plants: Protection against abiotic stress. Plant Biol. 2014, 16, 1-8. [CrossRef]

27. Peterbauer, T.; Richter, A. Biochemistry and physiology of raffinose family oligosaccharides and galactosyl cyclitols in seeds. Seed Sci. Res. 2001, 11, 185-197. [CrossRef]

28. Slewinski, T.L.; Braun, D.M. Current perspectives on the regulation of whole-plant carbohydrate partitioning. Plant Sci. 2010, 178, 341-349. [CrossRef]

29. Kozlowski, T.T. Carbohydrate sources and sinks in woody plants. Bot. Rev. 1992, 58, 107-222. [CrossRef]

30. Yarmolinsky, D.A.; Zuker, C.S.; Ryba, N.J.P. Common Sense about Taste: From Mammals to Insects. Cell 2009, 139, $234-244$. [CrossRef] [PubMed]

31. Lee, A.; Owyang, C. Sugars, Sweet Taste Receptors, and Brain Responses. Nutrients 2017, 9, 653. [CrossRef] [PubMed] 